http://dx.doi.org/10.18778/0208-6050.95.02

KINGA GRZEGORZEWSKA

(UNIWERSYTET ŁÓDZKI)*

\title{
Rola kobiet w hiszpańskich wyprawach zdobywczych w Ameryce Środkowej i Południowej w XVI w.
}

Sukces pierwszej wyprawy Krzysztofa Kolumba zapoczątkował proces tworzenia zamorskiego imperium Hiszpanii ${ }^{1}$. Z poszerzaniem wiedzy geograficznej o terenach odkrywanych przez Europejczyków wzrastała chęć penetrowania kolejnych terytoriów. Pierwszym czynnikiem zachęcającym do dalszej ekspansji było pragnienie bogactw, zdobywanych $\mathrm{w}$ zamian za poniesione trudy bądź bezpośrednio w postaci złota, bądź jako nadziały ziemi. Można zauważyć, że prawdziwy zapał do podbojów nastąpił po sukcesie Hernána Cortésa, któremu udało się podbić potężne imperium Azteków ${ }^{2}$ w latach 1519-1521. Kolejny wzrost liczby emigracji do Nowego Świata nastąpił po odkryciu i podporządkowaniu Koronie bogatego państwa Inków. Przybywający do Ameryki Hiszpanie, olśnieni widokiem cywilizacji tak innych, ale jednocześnie wspaniałych, wierzyli, że trafili do mitycznych krain. Nic dziwnego, że spodziewano się odkrycia kolejnych bogatych kultur. W Nowym Świecie krążyły opowieści o krainie Amazonek, El Dorado czy siedmiu miastach Ciboli ${ }^{3}$. Popularne legendy skłaniały do

${ }^{*}$ Wydział Filozoficzno-Historyczny, Instytut Historii, Katedra Historii Nowożytnej.

${ }^{1} \mathrm{Z}$ prawnego punktu widzenia w XVI w. Półwysep Iberyjski był podzielony między trzy organizmy państwowe: Portugalię, Kastylię i Aragonię. Termin „Hiszpania”, obejmujący dwa ostatnie królestwa, bardziej odnosi się do określenia społeczności niż bytu państwowego. Ponieważ niektórzy badacze uważają, że wraz z małżeństwem Izabeli Kastylijskiej i Ferdynanda Aragońskiego doszło do unifikacji terytorialnej i rozpoczęto budowę jednego państwa, w artykule będę używała wymiennie określenia „Hiszpania”, „Korona”, „Kastylia i Aragonia”. Vide: F. K u b i a c z y k, Między wojna a dyplomacją. Ferdynand Katolicki i polityka zagraniczna Hiszpanii w latach 1492 1516, Kraków 2010, s. 54-84.

${ }^{2}$ Określenie „Aztekowie” nie jest nazwą ścisłą: dawni mieszkańcy Meksyku nie używali tego określenia, zostało ono spopularyzowane w XVIII w. Vide: H. T h o m a s, Podbój Meksyku, Katowice 1998, s. 12. Ze względów zwyczajowych będę jednak używała go w tekście.

${ }^{3}$ Mityczne opowieści o krainach pełnych złota przez długi czas zachęcały do wyruszania w nieznane przez kolejne hiszpańskie wyprawy. Dzieje tych ekspedycji są zazwyczaj dramatyczne, przeczesywano bowiem tereny dzikie, niebezpieczne. Wiele z tych wypraw zakończyła się klęską. Vide: A. T a r c z yń ski, Wartości i postawy w obliczu zderzenia systemów kulturowych. Hiszpańscy 
podejmowania kolejnych wypraw odkrywczych. Chętnych do nich nie brakowało, ponieważ codzienna egzystencja w Ameryce, zwłaszcza w pierwszych latach osadnictwa, nie należała do najłatwiejszych. Głód, choroby, trudny klimat, niedostatek artykułów, do których Europejczycy przywykli - wszystkie te czynniki sprawiały, że osadnicy mając do wyboru codzienne trudy egzystencji w świeżo powstałych miastach, decydowali się na udział w wyprawie, z której mieli nadzieję powrócić wzbogaceni i okryci chwałą zwycięzców.

Czynniki, które wpływały na udział mężczyzn w wyprawach zdobywczych, są jasne. Wielu zdobywców ${ }^{4}$ wyraźnie wskazywało motywy, jakimi się kierowali, podejmując decyzję o wyruszeniu w nieznane. Artykuł ten chciałabym poświęcić przedstawicielkom płci pięknej, które $\mathrm{z}$ różnych przyczyn decydowały się uczestniczyć w takich przedsięwzięciach. W tytule piszę skrótowo o wyprawach zdobywczych, ale mam na myśli wyprawy, których charakter można określić jako: odkrywcze, kolonizacyjne (więc takie, w których planowano założenie miasta), mające na celu podbój. Rozgraniczanie rodzajów tych ekspedycji wydaje mi się niepotrzebne, ponieważ często podczas wyprawy, której celem było zbadanie danego terenu, podejmowano decyzję o rozpoczęciu osadnictwa, a przedsięwzięcia mające na celu kolonizację kończyły się fiaskiem i przynosiły jedynie informacje geograficzne odnośnie do przebytych terenów.

W wyprawach brało udział wiele kobiet, zarówno Hiszpanek, jak i Indianek. Towarzyszyły one mężczyznom, pełniąc różne funkcje: służących, kucharek, praczek, tragarek, ale także thumaczek. Podczas organizacji przedsięwzięć, których zadaniem był rekonesans terenów zupełnie nieznanych, kobiety hiszpańskie stanowiły zazwyczaj niewielki procent wyprawy, a uczestnicy starali się uzyskać pomocnice w czasie podboju. Przykładem może być ekspedycja Hernána Cortésa z 1519 r. Uczestnik tego przedsięwzięcia, Bernal Díaz del Castillo, w swojej relacji z wyprawy ${ }^{5}$ wielokrotnie opisuje, jak ważny był udział kobiet. Mężczyźni nie potrafili zazwyczaj przyrządzić potraw z produktów żywnościowych im nieznanych lub niedawno przez nich poznanych, dlatego niezwykle ważne oprócz pozyskania żywności było również skorzystanie z usług Indianek, które gotowały dla żołnierzy. Jak pisał Díaz del Castillo: ,[...] w naszym obozie pozostał drugi namiestnik Pitalpitoque; zajął on szałasy oddalone od naszych i tam przychodziły Indianki, które piekły chleb kukurydziany, przynosiły kury, owoce i ryby. Korzystali z tego Kortez [pisownia nazwiska zgodna z polskim wydaniem tekstu -

zdobywcy XVI wieku wobec Nowego Świata, Bydgoszcz 2001, s. 156, 158, 166. O poszukiwaniu mitycznych bogactw również: idem, Podbój imperiów Inków i Azteków, Warszawa 2009, s. 169-230.

${ }^{4}$ Przykładowo: Hernán Cortés - H. C o r t é s, Listy o zdobyciu Meksyku, Gdańsk 1997; Pedro Pizarro - P. P i z a rro, Relacja o odkryciu i podboju Królestwa Peru, Gdańsk 1995; Pedro de Valdivia - P. d e V a l d i v i a, Cartas, wyd. José Toribio Medina, Sewilla 1929.

${ }^{5}$ B. D i a z d e 1 C a s ti 11 o, Pamiętnik żotnierza Korteza czyli prawdziwa historia podboju Nowej Hiszpanii, Warszawa 1962. 
K.G.] i oficerowie, którzy z nim jadali, my zaś, żołnierze, bylibyśmy pomarli z głodu, gdybyśmy nie zbierali mięczaków i nie łowili ryb"“6.

Kobiety mogły też być powodem sporów wśród uczestników wyprawy. Tubylcy chętnie dawali Indianki w podarunkach, jednak najwięcej najpiękniejszych niewolnic trafiało do oficerów. Díaz del Castillo opisuje, jakie oburzenie wywołało postępowanie Cortésa, który po ucieczce z Tenochtitlan po „smutnej nocy”, podczas pacyfikacji okolicy, zarządził zgromadzenie wszystkich pojmanych kobiet i dzieci. Miały one zostać napiętnowane gorącym żelazem. W nocy, z rozkazu Cortésa, uprowadzono piękne Indianki dla oficerów, pozostawiając jedynie „stare i brzydkie”. Wobec sprzeciwu żołnierzy i coraz większego niezadowolenia z działań dowódcy Cortés zadecydował, że odtąd ,brzydkie czy piękne niewolnice wystawiane będą na licytację i każda sprzedawana wedle swej wartości"8. Było to ważne, gdyż kobiety tubylcze traktowano jako łup, bardzo pożądany i świadczący o pozycji żołnierzy. Z drugiej strony, w opinii uczestników wyprawy Indianki ustępowały urodą Hiszpankom, a znalezienie pięknej było trudne 9 . Díaz del Castillo, pragnąc uzyskać urodziwą nałożnicę, zwrócił się z prośbą o taki podarunek do Montezumy. Władca Azteków, który darzył Bernala sympatią, spełnił jego prośbę, co niezwykle uradowało żołnierza ${ }^{10}$. Oprócz niewolnic Hiszpanie otrzymywali od tubylców Indianki pochodzące z miejscowej arystokracji. Były one przekazywane jako kandydatki na małżonki dla dowódców. Kacykowie z Cempoalu zaproponowali Cortésowi spowinowacenie się z ich krewnymi. Dowódca odmówił zawierania stałych związków z pogankami, dlatego też panny zostały ochrzczone i dopiero potem przekazane dowódcom ${ }^{11}$. Wtedy rozpoczął się m.in. długoletni związek Pedra de Alvarado, jednego z ważniejszych oficerów u boku Cortésa, $\mathrm{z}$ doñą Luisą (takie imię otrzymała na chrzcie córka Xicotengi, kacyka Tlaskali) ${ }^{12}$. Tubylcze kobiety z możnych indiańskich rodów ofiarowywane jako małżonki miały stanowić gwarancję pokojowych rela-

\footnotetext{
${ }^{6}$ Ibidem, s. 61-62.

${ }^{7}$ La noche triste - noc z 30 VI na 1 VII 1520 r., kiedy Hiszpanie zostali zmuszeni do opuszczenia Tenochtitlanu. Zginęło wówczas wielu zdobywców i ich indiańskich sojuszników.

${ }^{8}$ B. D i a z d e 1 C a s t i 11 o, op. cit., s. 222-223.

${ }^{9}$ Zwrot Diaza del Castillo: „piękna jak na Indiankę” pojawia się w jego relacji kilkukrotnie, vide: ibidem, s. 83, 118, 218.

${ }^{10}$ Ibidem, s. 164-165.

${ }^{11}$ Ibidem, s. 81.

${ }^{12}$ F.A. de Fuentes y Guz man, Historia de Guatemala ó recordación Florida, t. I, Madrit 1882, s. 94. Ciekawa jest kwestia, jak postrzegano związki łączące Hiszpanów z Indiankami. W początkach kolonizacji Korona Hiszpańska popierała takie małżeństwa. Kobieta była chrzczona, następnie odbywały się uroczyste zaślubiny w obrządku katolickim. Z upływem czasu Hiszpanie coraz mniej chętnie zawierali małżeństwa z Indiankami. Chcąc wykorzystać taki związek do swoich celów, często pojmowali żony w obrządku indiańskim, który dla nich nie miał mocy prawnej. Vide: J. L a f a y e, Konkwistadorzy, Warszawa 1966, s. 109.
} 
cji, przyjaźni sojuszników, mogły też być dowodem podległości lub dobrym argumentem w ewentualnej przyszłej walce o władzę. Dlatego konkwistadorzy czasem zabierali kobiety z rodziny królewskiej ze sobą jako zakładniczki. Tak postąpił Cortés podczas „smutnej nocy”. Hiszpanie, zmuszeni do opuszczenia Tenochtitlan, ewakuowali się także z podporządkowanymi im przedstawicielami arystokracji azteckiej. Cortés zabrał ze sobą m.in. córki Montezumy. Obie kobiety zginęły podczas odwrotu z miasta ${ }^{13}$.

Zdarzały się przypadki Indianek, które dobrowolnie przyłączały się do wyprawy. Taką sytuację opisał Díaz del Castillo. Podczas bytności uczestników ekspedycji na jednej z wysp jedyną osobą, która zdecydowała się nawiązać kontakt z Hiszpanami, była młoda Indianka. Opowiedziała ona nieznanym przybyszom swoją historię: pochodziła z Jamajki, z mężem oraz kilkoma innymi Indianami trafiła na wyspę $\mathrm{w}$ wyniku burzy, która porwała łódź, którą wyruszyli na połów. Jej mąż zginął w potyczce $\mathrm{z}$ mieszkańcami owej wyspy. Nie wiadomo, jaki był status tej „branki” w społeczeństwie indiańskim. Czy jej kontakt z Hiszpanami był podyktowany brakiem lęku o własny los, ze względu na ciężką sytuację, w jakiej się znalazła? Czy też została wysłana, aby dowiedzieć się, kim są przybysze? Zgodziła się pośredniczyć w kontaktach między Hiszpanami a Indianami, jednak tubylcy nie chcieli przybyć na wezwanie nieznajomych. Ciekawe jest to, że owa Indianka nie zdecydowała się powrócić do swej wsi, ale dobrowolnie wsiadła na statek i ruszyła $\mathrm{w}$ dalszą drogę $\mathrm{z}$ Hiszpanami. Wydaje się więc, że nie istniały więzi łączące ją z wyspą, a niepewna przyszłość musiała być lepsza od egzystencji, jaką wiodła wśród Indian. Diaz del Castillo nie pozostawił relacji o jej dalszych losach ${ }^{14}$.

W podboju imperium azteckiego przez Hiszpanów aktywnie uczestniczyła doña Marina ${ }^{15}$. Była ona córką azteckiego kacyka, pochodziła z miasta Peinala. Diaz del Castillo podaje, że po śmierci ojca i powtórnym zamążpójściu matki doña Marina została sprzedana w niewolę, aby nie stanowić zagrożenia dla władzy swego przyrodniego brata. Przez lata żyła jako niewolnica wśród Majów i została dana w podarunku Cortésowi. Ten szybko dostrzegł walory Mariny: była nie tylko piękna, lecz także inteligentna, ponadto znała język zarówno Majów, jak i Azteków ${ }^{16}$. Razem z Jeronimo Aguilarem, towarzyszem Cortésa, który spędził kilka lat w niewoli u Majów, stworzyli wspaniały tandem tłumaczy. Umożliwił on Cortésowi podbój państwa Montezumy: Marina thumaczyła z azteckiego na język Majów, natomiast Aguilar przekładał na hiszpański. Dzięki

\footnotetext{
${ }^{13}$ H. C o r té s, op. cit., s. 69-70.

${ }^{14}$ B. D i a z d e 1 C a st i 11 o, op. cit., s. 24-25.

${ }^{15}$ Jej prawdziwe imię nie jest znane, uczestnicy wyprawy Cortesa wymawiali je: Malintzin. Najczęściej jest opisywana tak, jak nazwali ją Hiszpanie, czyli doña Marina.

${ }^{16}$ B. D i a z d e 1 C a s ti 11 o, op. cit., s. 57-58.
} 
temu zdobywcy mogli doskonale porozumiewać się z Aztekami ${ }^{17}$. Doña Marina bardzo przysłużyła się Hiszpanom nie tylko jako tłumaczka, lecz także jako informatorka. Wkrótce po wejściu do Tenochtitlan pewna miejscowa Indianka zwierzyła się Malintzin, że większość kobiet i dzieci indiańskich schroniło się w lasach, a pod miastem znajdują się żołnierze azteccy planujący zaatakować Hiszpanów i ich zgładzić. Kobieta ta zaproponowała, że ukryje Malintzin na czas ataku. Jednak doña Marina opowiedziała o wszystkim Aguilarowi, a ten poinformował Cortésa. Hiszpanie mogli się więc do spodziewanego ataku przygotować ${ }^{18}$.

Oprócz Indianek służących w czasie wyprawy hiszpańskim żołnierzom w ekspedycji brało udział zazwyczaj wiele tubylczych kobiet, które wyruszały ze swymi mężami. Postrzeganie konkwisty jako przedsięwzięcia, w którym uczestniczył oddział liczący kilkuset ludzi i zwyciężający dziesiątki tysięcy Indian, jest błędem. Hiszpanie często korzystali z pomocy tubylców wrogo nastawionych do władcy. W Meksyku najwierniejszymi sprzymierzeńcami Cortésa byli Tlaskalanie. Wysyłali oni wielotysięczne kontyngenty żołnierzy, aby towarzyszyły hiszpańskiemu dowódcy. Za wojskami indiańskimi szły zaś zazwyczaj miejscowe kobiety. Ponieważ brakuje pewnych danych dotyczących liczby tubylczych żołnierzy w służbie Cortésa, określenie liczby Indianek towarzyszących mężom również jest niezwykle trudne.

W wyprawach brały także udział Hiszpanki. Nie było ich tak wiele jak kobiet indiańskich ${ }^{19}$, ale aktywnie wspomagały mężczyzn podczas podboju. Do ekspedycji Cortésa dołączyły przedstawicielki płci pięknej, które przybyły z oddziałami Pánfilo de Narvaeza ${ }^{20}$. Trudno określić, ile dokładnie ich było. Díaz del Castillo podaje, że w bitwie pod Otumbą 14 lipca 1520 r. zginęło pięć kastylijskich kobiet $^{21}$. Takiego losu udało się uniknąć małżonce Francisca Orellany, Anie de Ayala, która w 1545 r. wyruszyła z mężem w jego drugą, jak się okazało nieszczęśliwą, podróż w górę Amazonki. Uczestnicy wyprawy byli dziesiątkowani przez choroby, głód, ataki Idian. Orellana zmarł w trakcie ekspedycji, a jej niedobitki liczące około 25 osób, z Aną, zdołały dotrzeć do wybrzeży Wenezueli

${ }^{17}$ F. A n t o n, Kobieta $w$ dawnej Ameryce, Warszawa 1974, s. 7-8.

${ }^{18}$ H. C o r té s, op. cit., s. 19-20.

${ }^{19}$ Według obliczeń C.B. Vegi, dokonanych na podstawie „Katalogu pasażerów udających się do Indii”, między 1509 a 1559 r. do Nowego Świata wyemigrowało ok. 15 tys. Hiszpanów, z czego kobiety stanowiły ok. 5-17\%. W drugiej połowie XVI w. emigracja zwiększyła się do ok. 200 tys., z czego liczba kobiet wzrosła do ok. 40-50\%. Vide: C.B. V e g a, Conquistadoras. Mujeres heroicas de la conquista de América, Santa Maria 2012, s. 55.

${ }^{20}$ Został on wysłany przez gubernatora Kuby Diego Velazqueza, aby aresztować Cortésa i kontynuować podbój w imieniu gubernatora. Przybyło z nim wiele żołnierzy, koni, armat, a także kobiet, które miały brać udział w kolonizacji. Vide: H. K a m e n, Imperium hiszpańskie. Dzieje rozkwitu i upadku, Warszawa 2008, s. 263.

${ }^{21}$ B. D i a z d e $1 \mathrm{C}$ a s ti 11 o, op. cit., s. 213. 
i ocalić swe życie ${ }^{22}$. Okazywało się, że w sytuacjach kryzysowych kobiety potrafiły radzić sobie równie dobrze jak mężczyźni. Obrazuje to korespondencja Isabel de Guevara, która w 1536 r. wzięła udział w wyprawie Pedra Mendozy w okolice dorzecza Río de la Plata. Dwadzieścia lat później Isabel starała się o uzyskanie nadania ziemi i dlatego wystosowała list, w którym przedstawiła losy ekspedycji i aktywny udział kobiet w tym przedsięwzięciu: „Gdy przybyliśmy do portu Buenos Aires, nasza wyprawa liczyła 1500 osób, ale mieliśmy tylko niewiele pożywienia i zapanował taki głód, że po trzech miesiącach tysiąc osób już nie żyło. Mężczyźni tak osłabli, że wszystkie prace spadły na ramiona biednych kobiet, które prały odzież, pielęgnowały mężczyzn i dbały o ich czystość, przygotowywały im te nędzne resztki pożywienia, jakie jeszcze pozostały, pełniły warty, podsycały ogniska, ładowały kusze, kiedy trzeba było stoczyć walkę w Indianami, a nawet strzelały z armaty. Później zdecydowali się płynąć w górę rzeki Parany i podczas tej podróży kobiety stawiały żagle, sterowały statkami, sondowały głębokość, wylewały wodę, chwytały za wiosła, jeśli któryś z żołnierzy nie mógł wiosłować, i zagrzewały ich, by nie tracili odwagi. Zaprawdę zaś nikt ich nie zmuszał, żeby robiły te rzeczy. Tak przybyli do miasta Asunción. Tutaj czekały na kobiety nowe zadania: własnymi rękami karczowały lasy, oczyszczały pola, okopywały motykami ziemię, siały i zbierały plony. Czyniły to same bez żadnej pomocy, aż do czasu, kiedy żołnierze wykurowali się ze swej słabości" ${ }^{23}$. W tak trudnej sytuacji Hiszpanki zdecydowały się podjąć wszelkie starania, aby ocalić od zagłady całą wyprawę. W obliczu zagrożenia wykonywały typowo męskie zadania i robily to, jak mogły najlepiej. $Z$ listu tego wynika, że to zachowanie kobiet uratowało życie uczestników ekspedycji. Trzeba jednak brać pod uwagę to, że relacja Isabel de Guevara może być nieco przerysowana. Chcąc podnieść swoje zasługi, dobrać argumenty przemawiające za nadaniem jej ziemi, mogła przejaskrawić pewne wydarzenia. Natomiast fakt szerokiej działalności kobiet $\mathrm{w}$ razie nieobecności lub niedyspozycji mężczyzn wydaje się bezsporny.

Kolejną znaną uczestniczką wyprawy zdobywczej była Inés Suárez. W 1540 r. wyruszyła z ekspedycją Pedra de Valdivii do Chile. Droga na południe wiodła m.in. przez pustynię Atacama. Hiszpanom wkrótce zaczęło brakować wody i tylko umiejętności Inés uratowały uczestników wyprawy od śmierci. Kobieta potrafiła odnajdywać ukryte podziemne źródła, posługując się różdżką z gałęzi ${ }^{24}$. Przez całą drogę przez pustynię wskazywała odpowiednie miejsca, w których wykopywano studnie. Zaangażowała się również w walkę o władzę. Zazwyczaj podczas ekspedycji, zwłaszcza tych trudnych, a do takich należała hiszpańska

${ }^{22}$ A. T a r c z y ń s k i, Podbój imperiów..., s. 258-259.

${ }^{23}$ Cyt. za: H. K a me n, op. cit., s. 261.

${ }^{24} \mathrm{P}$. M a r i ñ o d e L o v e r a, Crónica del Reino de Chile, [w:] Colección de historiadores de Chile y documentos relatives a la historia nacional, t. VI, Santiago de Chile 1865, s. 39. 
wyprawa do Chile, dochodziło do walk o przywództwo. Również Valdivia musiał się zmagać z innymi pretendentami do władzy. Inés, która była jego kochanką, aktywnie wspierała dowódcę. Gdy do obozu Hiszpanów przybył Pero de la Hoz, konkurent Valdivii ${ }^{25}$, z zamiarem zamordowania dowódcy, to Inés storpedowała jego zamiary. Ponieważ Valdivia znajdował się poza obozem, zazdrosny pretendent do władzy, nie mogąc pozbawić go życia, zaczął nawoływać do buntu. Inés doprowadziła do uwięzienia Pera Sancha de la Hoz i przekazania go w ręce dowódcy, aby ten osądził spiskowca ${ }^{26}$. Dzięki działaniom kochanki Valdivia uniknął przykrych konsekwencji dalszej działalności konkurenta do władzy.

Umiejętność szybkiego i sprawnego działania przydała się także Inés podczas ataku Indian na niedawno założone hiszpańskie miasto Santiago. Pod nieobecność Valdivii, który z większością żołnierzy pacyfikował okolicę ${ }^{27}$, w nocy z 10 na 11 września $1541 \mathrm{r}$. miasto zaatakowały silne oddziały Indian. Inés zachowała zimną krew. Zauważyła, że celem ataku tubylców jest dom gubernatora, gdzie byli przetrzymywani pojmani wcześniej kacykowie. Zarządziła ich stracenie, a wobec zaskoczenia, jakie wywołał jej rozkaz, sama ścięła głowy indiańskim wielmożom. Widząc śmierć przywódców, tubylcy stracili zapał do walki i mieszkańcom Santiago udało się odeprzeć atak. Inés organizowała pomoc medyczną dla rannych żołnierzy oraz zadbała o bezpieczeństwo kobiet i indiańskiej służby, która pozostała wierna Hiszpanom, umieszczając ich w spokojniejszym miejscu i wyznaczając ludzi, którzy mieli ich chronic ${ }^{28}$.

Innym przykładem kobiety, która nie była tylko biernym uczestnikiem wyprawy, jest Isabel Barreto y Quiros. Była ona małżonką Álvara de Mendañii, z którym w 1595 r. wyruszyła w podróż morską w celu zbadania i skolonizowania wysp na Pacyfiku ${ }^{29}$. Nie była to udana wyprawa. Brak sukcesów w czasie

${ }^{25}$ Pero de la Hoz otrzymał w Hiszpanii dokumenty królewskie zezwalające mu na eksplorację wybrzeża Pacyfiku aż po Cieśninę Magellana. Valdivia natomiast dostał w 1539 r. od Francisca Pizarro, gubernatora Peru, pełnomocnictwa na organizację wyprawy do Chile. Obaj pretendenci zawarli ugodę, na mocy której stali się wspólnikami w podboju. Dalsze wydarzenia wskazały, że mimo układu obaj rozpoczęli rywalizację o dowództwo wyprawy. Od początku jednak de la Hoz cieszył się mniejszym poparciem niż Valdivia, jego działania skupiały się na knuciu intryg w celu pozbawienia władzy Valdivii, który w końcu skazał konkurenta na śmierć. $C f$. A. T a r c z y ń s k i, Podbój imperiów..., s. 276.

${ }^{26}$ Proceso de Pedro de Valdivia y otros documentos inéditos concernientes a este conquistador, wyd. D. Barros Arana, Santiago 1873, s. 31-32.

27 Tereny Chile zamieszkiwały wojownicze plemiona Araukanów, którzy nie chcieli podporządkować się Hiszpanom.

${ }^{28}$ J. d e V i v a r, Crónica y relación copiosa y verdadera de los reinos de Chile, Santiago de Chile 1966, s. 55.

${ }^{29}$ Jednym z celów wyprawy było znalezienie tajemniczego kontynentu, Australii, który miał się znajdować na Pacyfiku. Medaña brał udział w podobnym przedsięwzięciu w $1567 \mathrm{r}$. Wyprawa ta odkryła kilka wysp w archipelagu Salomona. Cf. C.B. V e g a, op. cit., s. 168-169. 
trwania ekspedycji i trudne warunki, z jakimi zmagali się Hiszpanie, sprawiły, że załoga zaczęła się buntować. Przywódcą tych wystąpień był oboźny Pedro Manrique. W konflikt między dowódcą a jego podkomendnym zaangażowana była Isabel. Początkowo broniła oboźnego przed gniewem małżonka ${ }^{30}$, ale $\mathrm{z}$ czasem, widząc, że zagraża on przywódczej pozycji Álvara, stała się zwolenniczką stracenia buntownika. Uczestnik, zarazem pilot wyprawy, Pedro Fernandez de Quiros opisuje, że Isabel miała wzywać do zamordowania oboźnego, krzycząc nawet, że jeżeli nie zrobi tego jej mąż, to ona za pomocą noża wykona wyrok ${ }^{31}$. Później oskarżała Manrique, że planował zgładzenie jej braci, męża i jej samej ${ }^{32}$. Ostatecznie oboźny, jako przywódca buntu, został skazany na śmierć. Isabel osiągnęła więc swój cel - pozbyła się człowieka, który zagrażał pozycji jej małżonka. Niestety Mendaña zmarł na malarię na wyspie Graciosa w październiku 1595 r. W testamencie wyznaczył żonę na swą następczynię, mianując ją gubernatorem odkrytych wysp. Isabel nie było dane objąć tej funkcji - nie podbito atrakcyjnych terenów ani nie udało się uzyskać wartościowych zdobyczy. Jednak takie nadanie świadczyło o ogromnym szacunku, jakim Mendaña darzył swą żonę, a także jego wierze, że to Isabel będzie w stanie skutecznie wykonywać tak ważne zadania. Nie pomylił się: gdy w grudniu 1595 r. zmarł także Lorenzo Barreto, brat Isabel i kapitan główny wyprawy, to właśnie wdowa po Mendañi przejęła kierownictwo nad całą ekspedycją. Musiała się zmierzyć z opozycją załogi, która sprzeciwiała się rządom kobiety. Isabel wywalczyła przejęcie pełnej władzy nad wyprawą. Duże znaczenie miało to, że zyskała poparcie pilota wyprawy Pedra Fernández de Quiros, który wyraźnie podporządkował się pani kapitan; bez szemrania wypełniał jej rozkazy oraz okazywał szacunek. Isabel zmuszona była zmierzyć się $\mathrm{z}$ buntem załogi wywołanym zbyt małą ilością jedzenia. Ze sprzeciwem spotkała się też jej decyzja o zmianie kierunku podróży. Do tej pory wyprawa podążała w kierunku północno-wschodnim, aż dotarła do Filipin. Isabel postanowiła wracać do Peru. Jak się okazało, była to właściwa decyzja, a wyprawa kierowana przez zgodny tandem Isabel i pilota szczęśliwie, choć bez odniesionego sukcesu, dotarła z Manili do Peru ${ }^{33}$.

Obecność kobiet w czasie wyprawy nie zawsze była dobrze postrzegana i przyczyniała się do sukcesu przedsięwzięcia. Wspomniana Isabel Barreto y Quiros była bardzo krytykowana przez załogę z powodu nadmiernej liczby ubrań, które zabrała ze sobą w podróż. Nielubiana żona dowódcy była więc dodatkowym argumentem do wszczęcia buntu przeciwko Mendañi ${ }^{34}$. Dowódcy

${ }^{30}$ The voyages of Pedro Fernandez de Quiros, 1595 to 1606, ed. C. Markham, t. I, London b.r.w., s. 12 .

${ }^{31}$ Ibidem, s. 70.

${ }^{32}$ Ibidem, s. 76.

${ }^{33}$ C.B. V e g a, op. cit., s. $168-169$.

${ }^{34}$ The voyages..., s. 56. 
udało się załagodzić napiętą sytuację i ostatecznie załoga podporządkowała się Isabeli, ale nie były to częste przypadki. Hiszpanie oburzeni wszechwładzą Inés Suárez i wpływem, jaki wywierała na Pedra de Valdivię, doprowadzili do jej oddalenia przez gubernatora ${ }^{35}$. Natomiast zupełną klęską zakończyła się wyprawa Pedra de Ursui, która wyruszyła w 1560 r. na poszukiwanie mitycznych krain Omagua i El Dorado. Ursúa postanowił wziąć ze sobą swoją kochankę, Inés de Atienza, kobietę niezwykle urodziwą. Dowódca zabrał ukochaną wbrew wielu radom, aby tego nie czynił: jej obecność dawała zły przykład, piękna kobieta wzbudzała też silne emocje wśród innych członków wyprawy, podsycając zawiść czy niechęć do dowódcy. Oprócz tego obecność kobiety traktowanej jak dama nastręczała wiele problemów logistycznych: Inés towarzyszyła liczna kobieca świta, dla pań zabrano także pokaźny bagaż. Wobec faktu, że w czasie wodowania szaland ${ }^{36}$ część $\mathrm{z}$ nich zatonęła, co sprawiło, że Ursúa musiał ograniczyć liczbę zabranych koni, przeznaczanie cennego miejsca na kufry dam nie zostało dobrze przyjęte przez załogę. Dowódca z początku ukrywał to, że zabrał na wyprawę kochankę: płynęła ona na końcu w osłoniętej łodzi. Gdy jednak obecność Inés się wydała, Ursúa zaczął się zachowywać w sposób nierozsądny i podważający jego autorytet przywódcy ${ }^{37}$. W widoczny sposób dbał o wszelkie wygody Inés. Aby jej zaimponować, kazał budować imponujące obozy na postojach, urządzał dla niej pokazy swych wojsk ${ }^{38}$. Uczestnicy wyprawy zapewne nie byli zachwyceni, że tyle wysiłku wkładano w zabawianie kochanki dowódcy. Ponieważ ekspedycja nie napotykała bogactw mogących poprawić nastroje żołnierzy, wkrótce rozpoczęły się spiski i szemrania przeciwko Ursúi. Dowódca nie potrafił skutecznie stłumić buntu. Reagował mało stanowczo i wręcz błędnie: głośno wyrażających swoje niezadowolenie karał, skazując ich na wiosłowanie na brygantynie, którą płynęła Inés. $\mathrm{Z}$ jednej strony nie była to kara zbyt dotkliwa, $\mathrm{z}$ drugiej - skazani uważali to za ogromny despekt, kojarząc Inés z nieudanym przywództwem Ursui. Dodatkowo zazdrość o piękną kobietę podsycała nastroje niechęci wobec dowódcy. W dniu 1 stycznia 1561 r. Ursua został zamordowany. Rozpoczęły się walki o władzę, w efekcie których na czele wyprawy stanął okrutny Lope de Aguirre. Stosował on wobec swoich ludzi terror, którego ofiarą padła też Inés, zamordowana w połowie $1561 \mathrm{r} .{ }^{39} \mathrm{~W}$ tym przypadku obecność kobiety doprowadziła do śmierci przywódcy.

Kobiety uczestniczyły w licznych wyprawach organizowanych przez Hiszpanów w XVI w. Były to zarówno Europejki, jak i Indianki. Brak dokładnych

${ }^{35}$ Vide: Proceso de Pedro de Valdivia...; A. d e G o n g o r a M a r m o l e j o, Historia de Chile desde un descubrimiento hasta el año de 1575, b.m.w. 2003, s. 208.

${ }^{36}$ Płaskodenne łodzie, służyły głównie do transportu zwierząt.

${ }^{37}$ A. T a r c z y ń s k i, Podbój imperiów..., s. 260-262.

${ }^{38} \mathrm{~J}$. d e C a s t e 11 a n o s, Elegías de varones ilustres de Indias, Madrit 1857, s. 159.

${ }^{39}$ A. T a r c z y ń s k i, Podbój imperiów..., s. 262-263. 
danych statystycznych nie pozwala dokładnie określić ich procentowego udziału w poszczególnych przedsięwzięciach, ale liczne wzmianki źródłowe pozwalają wyodrębnić takie przypadki. Kobiet tubylczych było zazwyczaj więcej w poszczególnych ekspedycjach, ale wynikało to z tego, że w wyprawach uczestniczyło więcej służby indiańskiej niż hiszpańskich zdobywców. Przedstawicielki płci pięknej odgrywały różne role w trakcie wypraw. Oprócz różnych posług, jakie wykonywały, mogły pełnić znaczące funkcje jako tłumaczki, informatorki (tu Indianki) lub brały aktywny udział w wyprawach, angażując się w rozmaite przedsięwzięcia. $\mathrm{W}$ razie potrzeby przejmowały męskie zadania, zdobywały pożywienie, a nawet walczyły z bronią w ręku. Angażowały się w walki o władzę, doradzały, dowodziły. Można zauważyć jednak, że kobiety rzadko pojawiają się w czasie wyprawy jako osoby samotne. Ich udział w ekspedycjach (oprócz przypadków przymusowego uczestnictwa przez niewolnice indiańskie) zazwyczaj wiązał się z osobą mężczyzny - kobiety wyruszały, aby towarzyszyć mężom lub kochankom. Zapewne wynikało to z panujących warunków: trudno było określić, jak długo wyprawa potrwa (a mogła trwać nawet kilka lat), a także tego, że w przypadku odnalezienia terenu nadającego się do kolonizacji rozpoczynało się budowanie miasta, a osadnictwo wiązało się ze sprowadzaniem kobiet na zasiedlane tereny. To właśnie przedstawicielki płci pięknej były gwarantem trwałej obecności Hiszpanów na zdobywanych terenach. Gdy mężczyźni wyruszali, aby przemierzać wciąż nowe miejsca, to kobiety stanowiły podstawę osiadłego trybu życia. Jako podsumowanie przytoczę słowa historyka Henry'ego Kamena: kobiety ,uczestniczyły [...] we wszystkich etapach budowy hiszpańskiego imperium, ${ }^{\prime 4}$.

KINGA GRZEGORZEWSKA

\section{The participation of women in the Spanish conquests in Central and South America in the $16^{\text {th }}$ century}

I would like to present in this article the question of the participation of women in the martial and exploratory expeditions to Central and South America organized by the Spanish in the sixteenth century. Usually, descriptions of the expeditions are limited to the male participants, which is why in this article I would like to direct attention to the participation and activity of women in such enterprises. Native women performed serving functions of cooks, laundresses, porters, or aided the Spanish as interpreters and provided them with information. Sometimes they took part in expeditions in order to accompany their husbands or paramours, as female Indians were often gifted to the conquerors as slaves. Spanish women often joined expeditions of which one of the

\footnotetext{
${ }^{40}$ H. K a m e n, op. cit., s. 263.
} 
aims was to settle newly conquered territories. They would set off together with their husbands or paramours, often enjoying privileges which aggravated the other participants. Women took a variety of tasks upon themselves, frequently advising leaders in problematic situations. The article presents various forms of activity of the members of the fair sex during the expeditions, and their status and influence on the success of the undertakings. 